\title{
Tabaco y COVID-19. ¿Se reducirá su consumo después de la pandemia?
}

\section{Tobacco and COVID-19. Will their consumption be reduced after the pandemic?}

\author{
Javier Cifuentes-Faura' ${ }^{(1)}$
}

\begin{abstract}
The severe acute respiratory syndrome type 2 coronavirus or SARS-CoV-2, widely known as COVID-19, is affecting millions of people worldwide and causing thousands of deaths. In addition, this type of coronavirus could have a greater impact on people who have or have had problems with drug use such us tobacco.
\end{abstract}

Keywords: COVID-19; tobacco; ACE2

\section{RESUMEN}

El coronavirus del síndrome respiratorio agudo severo tipo 2 o SARS-CoV-2, ampliamente conocido como COVID-19, está afectando a millones de personas en todo el mundo y causando miles de muertes. Además, este tipo de coronavirus podría tener un mayor impacto en las personas que tienen o han tenido problemas con el uso de drogas como el tabaco.

Palabras clave: COVID-19; tabaco; ACE2

${ }^{1}$ M.Sc. Investigador University of Murcia, Spain. Correspondencia: javier.cifuentes@um.es
People with substance use problems may be more likely to experience emotional distress during quarantine. On the other hand, people with more emotional distress are at greater risk of developing addiction during this time of health crisis.

It is important for people who have successfuIly stopped using drugs and other substances to maintain their motivation and seek new strategies to maintain healthy routines and prevent relapses, as confinement measures can lead to stress and emotional difficulties.

One of the most widely used legal drugs in the world is tobacco. Smokers are more vulnerable to infection by any virus $(1,2)$ and are more likely to develop chronic obstructive pulmonary disease (COPD) (3).

Recent studies show that tobacco is not protective against SARS-CoV-2 infection. Increasing evidence suggests that cigarette smoke stimulates the lungs to produce more ACE2 (angiotensin-converting enzyme 2), the protein that the coronavirus traps and uses to enter human cells (4).

Increased expression of ACE2 in the lungs of healthy smokers has been reported $(5,6)$. Studies in mice have established that cigarette smoke may trigger the expansion of a subpopu-

Citación (Vancouver): Cifuentes-Faura. Tabaco y COVID-19. ¿Se reducirá su consumo después de la pandemia?. Rev Avances en Salud; 2020. (4)2 :8-9 . doi: $10.21897 / 25394622.2321$ 
lation of respiratory epithelial cells that express ACE2 in a dose-dependent manner (4). Active smokers and COPD patients have increased expression of ACE2 in the lungs (7), which could lead to a four-fold increased risk of developing severe COVID-19 $(8,9)$.

Tobacco use is also a major risk factor for non-communicable diseases such as cardiovascular disease, cancer, some respiratory diseases and diabetes, and people with these diseases are at increased risk of developing severe symptoms if they are affected by COVID-19. Opiate users are at greater risk of suffering complications from COVID-19 due to the effect of the drug on the respiratory and pulmonary systems. $\mathrm{WHO}$ is cautious at this stage and states that there is not enough information to confirm any link between tobacco or nicotine and the prevention or treatment of COVID-19 (10), although there are indications that tobacco exacerbates COVID-19 complications.

\section{REFERENCIAS}

1. Lawrence, H., Hunter, A., Murray, R., Lim, W.S., McKeever, T. Cigarette smoking and the occurrence of influenza - systematic review J Infect. 2019, 79, pp. 401-406

2. Han, L. Ran, J., Mak, Y.W., Suen, L.K, Lee, P.H., Peiris, JSM etal. Smoking and Influenzaassociated Morbidity and Mortality: A Systematic Review and Meta-Analysis Epidemiology. 2019, 30, pp. 405-417

3. Ji, W., Lim, M.N., Bak, S.H., Hong, S.H. Han, S.S. Lee, S.J. et al. Differences in chronic obstructive pulmonary disease phenotypes between non-smokers and smokers. Clin Respir J. 2018, 12, pp.666-673

4. Smith, J.C., Sausville, E.L., Girish, V., Yuan, M.L., John, K.M. Sheltzer, J.M. Cigarette smoke exposure and inflammatory signaling increase the expression of the SARS-CoV-2 receptor ACE2 in the respiratory tract. 2020, Dev Cell.

5. Cai, G., Bosse, Y Xiao, F. Kheradmand, F. Amos, C.I. Tobacco Smoking Increases the Lung Gene Expression of
This could lead to a future increase in public awareness of the severity of this pandemic as there is likely to be a reduction in the number of people who smoke, due to fears of increased transmission of COVID-19 from themselves and their close relatives. We know about the complication of quitting smoking and nicotine addition, but the severe psychological impact that COVID-19 may have caused the death of a family member may generate shock and greater fear in the subject who smokes, leading to a decrease in consumption.

In the meantime, in this field of drugs, especiaIly in one of the most common such as tobacco, high quality and ethically approved studies and research should continue to be carried out that will contribute to improving individual and public health. Likewise, prevention campaigns aimed at the entire population must continue to be promoted.

ACE2, the Receptor of SARS-CoV-2. Am J Respir Crit Care Med. 2020. 6. Brake, S.J., Barnsley, K., Lu, W., McAlinden, K.D., Eapen, M.S., Sohal, SS. Smoking Upregulates AngiotensinConverting Enzyme-2 Receptor: A Potential Adhesion Site for Novel Coronavirus SARSCoV-2 (Covid-19). J Clin Med. 2019, 9

7. Leung, J.M., Yang, C.X., Tam, A., Shaipanich, T., Hackett, T.L, Singhera G.K., et al.. ACE-2 Expression in the Small Airway Epithelia of Smokers and COPD Patients: Implications for COVID-19. Eur Respir J. 2020.

8. Zhao, Q., Meng, M., Kumar, R., Wu, Y. Huang, J. Lian N., et al. The impact of COPD and smoking history on the severity of Covid-19: A systemic review and meta-analysis. J Med Virol. 2020.

9. Wang, B., Li, R., Lu, Z. Huang, Y. Does comorbidity increase the risk of patients with COVID-19: evidence from meta-analysis. Aging (Albany NY). 2020, 12, pp. 6049-6057

10. WHO Statement: Tobacco Use and COVID-19. Available at: https:// www.who.int/es/news-room/detail/11-05-2020who-statement-tobacco-use-and-covid-19 